\title{
An Assessment of the Legal Provisions for the Maintenance and Welfare of Parents and Senior Citizens Act, 2007 and the Maintenance and Welfare of Parents and Senior Citizens (Amendment) Bill, 2019 in India
}

\author{
Mumtaz zabeen khan \\ Correspondence: Mumtaz zabeen khan, Assistant Professor, School of Law, IEC University, Baddi (HP), India.
}

Received: March 5, 2021

Accepted: March 25, $2021 \quad$ Online Published: March 29, 2021

doi:10.11114/ijlpa.v4i1.5201

URL: https://doi.org/10.11114/ijlpa.v4i1.5201

\begin{abstract}
Longevity is a fundamental dream of all living things. In traditional Indian culture, elders have been accorded a high status and a symbol of reverence. Each child has a virtuous duty to hold his parents as true images of Brahma, Vishnu, and Mahesh, which God has put on them. However, the winds of change are blowing all around us, and new situations are arising. The elderly have faced economic, social, and political challenges as a result of the nuclear family structure, modernization, industrialization, population growth, globalisation, rising unemployment, and poverty, among other factors. Physical, physiological, and emotional violence, as well as a lack of financial support, add insult to injury. Is it for this that a parent has dedicated his whole life? This shift in conduct necessitates the provision of defence and social welfare. Parents were increasingly oppressed, as they were compared to Godly creatures and addressed as "Matru-deo Bhava," "Pitrudeo Bhava," and so on, which was not the customary common practise. The author was moved to tears by the current situation, so he conducted this research study on the legislation for The Maintenance and Welfare of Parents and Senior Citizens Act, 2007, in accordance with the provisions of Article 41 read with Entry 23 of the Concurrent List (Schedule VIII) of the Constitution of India. To bring to light which protective legislations, as well as Penal Provisions, were designed to provide social protection to elderly parents? And what amendments to current laws would be needed to improve Indian cultural roots? And how effective has the judiciary been in promoting and preserving the right of this vulnerable group of people, namely older parents and senior citizens, to live in dignity?
\end{abstract}

Keywords: analysis, Existing law, Improvisation, legislative lacunas, Amendment Bill, appraisal

\section{Introduction}

Old age is an indispensable stage of life which a man cannot refute except untimely death. Traditionally parents are treated as a pious form of God. Duty to maintain old aged parents is a general notion and has been acknowledged universally. The great saint Tamil poet "Avvaiyar" said "Annaiyum Pithavum Munnari Deivam" which means mother and father are the first God known to the children. There was a time when at the behest of the father, Hindu God Shri Ram ji left home by leaving all material luxuries at palace and went to exile for keeping the honor of words of the father. Unfortunately, God Shri Ram Ji like kin is hard to found in this era of $21^{\text {st }}$ century. The nuclear family system, lack in traditional family bonds, industrialization, urbanization, globalization, demographic shift, new life style, education, etc., all are contributing factors responsible towards the disintegration of traditional norms and status of the senior citizens have deteriorated. May be this entire is due to the wrong conceived ideas of materialistic living of western societies? This leads to increasing number of incidents reported with senior citizens. Even sometimes senior citizens are recklessly abandoned to lead a life like a stray dog, under some extreme situations they are thrown away from their own house like a useless piece of paper, ultimately found begging on roads in their age of salvation. It is ground reality of life that the children after grabbing riches of their aged parents, felt no shame in showing the way to door to old parents. They were forced to abandon home for the mercy of death. Is it this for which a parent spent his entire life for? Parents, formerly wished-for great advantage to the family, at the present treated as problem and frequently maltreated. The ethical obligation under moral law to maintain parents, is accepted by all while, the degree of such duty varies from society to society. In olden era, the Hindu sons were under the obligation to keep their old-aged parents who were unable to keep themselves out of their own earning and property, and were even liable to pay off standing debts as pious obligation; rather it was a purely private lawful obligation enforceable by the state. Likewise, Muslim law casts responsibility on offspring to maintain their old 
aged parents. The commitment to maintain is dependent on the condition of having means to do so. By the steady decline in compliance with this moral duty, the legal provisions were added for the protection of parents under social laws. The Indian Constitution, for example, stipulates "The State shall, within the limits of its economic ability and growth, make effective provision for securing the right to work, to education, and to public assistance in cases of unemployment, old age, illness and disablement, and other cases of undeserved want," according to the Indian Constitution. "A person's duty to sustain his or her aged or infirm parent extends in so far as the parent is unable to maintain himself or herself out of his or her own earnings or other property," according to the Hindu Adoption and Maintenance Act. The secular clause was added to the Code of Criminal Procedure, which holds people of all faiths, including married daughters, responsible for their parents' upkeep. It's surprising to see that, after so many provisions, the issue remains unaddressed. Taking into account the above harsh realities, lawmakers have solemnly endeavoured to pass the Maintenance and Welfare of Parents and Senior Citizens Act, 2007, in order to make the process simpler and less costly. It seeks to alleviate the sufferings of this vulnerable segment of society while also ensuring that children do not flee from their moral responsibilities, which might have been taught to every soul by God himself.

\section{Objective of the Research Paper}

- To identify the problems faced by the old aged parents and senior citizens.

- To bring into light the international Endeavour's for protection of senior citizens.

- To throw light on National efforts undertaken by government of India for the welfare and protection of Senior citizens.

- To discuss the Indian Laws available for the welfare and protection of Senior citizens.

- To discuss what changes were aimed by the implementation of "The Maintenance And Welfare of Parents And Senior Citizens (Amendment) Bill, 2019

- To identify the lacunas in the existing legislation

- To make suggestion for the effective implementation of the Act, 2007.

\subsection{Problems Faced by Senior Citizens and Aged Parents}

Problems faced by the senior citizens are as follows:

1) Financial problems include evils like income deficiency, unemployment, and monetary insecurity.

2) Physical as well as physiological troubles count on physical condition and medicinal matters, mala-nutrition, and inadequate housing etc.

3) Legal problems which covers follows pressures and fear of following offences being faced during the prolonged legal proceeding resulting mental Harassment, Defamation, Assault, Criminal intimidation, wrongful restraint, Breach of trust, fraud, mischief, nuisance, criminal misappropriation like if a senior citizen proceed to take his property back from disobedient son and daughter, then Daughter-in law misuse the provisions of Domestic Violence Act, Wrongfully removing and disposing the property of the senior citizens, illiteracy towards their rights are among the other problem.

4) Psycho-social problem includes problems like social maladjustment and psychological in addition to the issues of elder abuse etc.

\subsection{The International Endeavour's for Protection of Senior Citizens}

1) The topic of ageing was first addressed at the United Nations in 1948, following Argentina's invitation. In 1969, the issue was brought up again in Malta for discussion. In 1971, the United Nations General Assembly asked the Secretary-General to prepare a detailed report on the elderly and to develop guidelines for national and international cooperation. In the year 1978, the Assembly decided to support a World Conference on Aging. As a result, in July and August of 1982, the World Assembly on Aging was held in Vienna, where an International Plan of Action on Aging was adopted. The Plan's aim was to strengthen countries' ability to deal effectively with the issue while also promoting social and financial stability. Later, the Assembly encouraged the Secretary-General to continue working to ensure that the Plan is implemented effectively.

2) In 1992, the United Nations General Assembly passed a resolution declaring 1999 to be the International Year of the Elderly.

3) The International Day for the Elderly was proclaimed by the United Nations General Assembly on October 1 st. 
4) On December 16, 1991, the United Nations General Assembly adopted eighteen principles grouped into five clusters, namely, democracy, engagement, treatment, self-fulfillment, and dignity of the elderly. ${ }^{1}$

\subsection{National Efforts Under the Indian Laws Available for the Welfare and Protection of Senior Citizens}

1) On January 13, 1999, the Government of India approved the National Policy for Older Persons in order to expedite welfare initiatives and motivate the elderly in ways that are beneficial to them. The following major measures were included in this policy:

- Establishment of a pension fund to provide security to those who have worked in the unorganised sector;

- Every 3-4 districts will have old age homes and day care centres built.

- Resource centres and re-employment bureaus for people over the age of 60 ,

- Concessional rail/air fares for travel within and between cities, e.g., a $30 \%$ train discount and a $50 \%$ Indian Airlines discount.

- Enacting legislation requiring all public hospitals to have mandatory geriatric treatment.

2) The Ministry of Justice and Empowerment has announced the creation of the age-well Foundation, a National Council for Older People. It will seek the opinions of the elderly on steps to make their lives easier.

3) Aims to teach schoolchildren about the value of living and working with the elderly. The establishment of a 24-hour support line and the prevention of social ostracism of the elderly are being pursued.

4) Government policy promotes the timely payment of pensions, provident funds (PF), gratuities, and other benefits to save superannuated people from financial hardship. It also supports the creation of tax policies that are responsive to the needs of the elderly.

5) Their health care needs are also given top priority in the policy.

6) The elderly are eligible for tax breaks under Sections 88-B, 88-D, and 88-DDB of the Income Tax Act.

7) The Life Insurance Corporation of India (LIC) has a number of schemes for senior citizens, including Jeevan Dhara Yojana, Jeevan Akshay Yojana, Senior Citizen Unit Yojana, and Medical Insurance Yojana.

8) Former Prime Minister A.B. Bajpai launched the 'Annapurana Yojana' to help the elderly. Unattended elderly people are given $10 \mathrm{~kg}$ of food every month as part of this yojana.

9) It is suggested that $10 \%$ of the houses built under government schemes for the urban and rural low-income segments be made available to the elderly on a low-interest loan.

\subsection{Statutory Provisions for the Protection of Senior Citizens and Aged Parents Under Indian Laws}

\subsubsection{Constitutional Safeguard}

"Right to work, education, and public assistance under such circumstances: "Within the limits of economic ability and growth, the State shall make adequate provisions for securing the right to work, education, and public assistance in cases of unemployment, old age, illness, and disablement, and other cases of undeserved want."

"Promotion of the educational and economic interests of....... and other weaker sections: The State shall promote with particular attention the educational and economic interests of the weaker sections of the people......and shall protect them from social inequality and other types of exploitation"3

These provisions are included in Chapter IV of the Indian Constitution, titled Directive Principles. Article 37 of the Directive Principles states that no court of law will enforce them. Directive Principles, on the other hand, place constructive responsibilities on the state.

\subsubsection{Legal Provisions for Providing Maintenance Under Personal Laws}

\section{1) Liability of Hindu Children to maintain their aged parents}

Even in early Hindu texts, the duty of sons to support their elderly parents who were unable to support themselves out of their own earnings and property was recognised. And this duty was not contingent on, or limited in any way by, the ownership of family property. It was a personal legal responsibility that the sovereign or the state could impose. The Hindu Adoption and Maintenance Act, 1956, contains a constitutional provision for the maintenance of parents under Hindu personal law. This Act is India's first personal law legislation to place a financial duty on children to support their parents. As the section's wording indicates, the obligation to support parents is not limited to sons; daughters have

\footnotetext{
1 Ibid.

2 Art. 41, The Constitution of India.

3 Art. 46, The Constitution of India.
} 
an equal responsibility to their parents. It's important to remember that this Act only applies to parents who are financially unable to support their children from any other means.

2) Slamic Law

In Muslim law, the word "maintenance" is referred to as "nafaqa," which means "what a person spends over his family." Hedaya describes 'maintenance' as all that is needed to sustain life, such as food, clothing, and lodging. There are three reasons why one person must preserve the other: I marriage, (ii) friendship, and (iii) land. The highest level of obligation arises from marriage; the second level arises when one person has "means" and the other is "indigent." It is true that the responsibility to care for one's children is a personal one. The duty to care for one's elderly and infirm parents occurs only when one is in good financial standing and the parents are poor. The duty to retain other relationships occurs only when one is in easy circumstances and the ties are weak, and it only applies to those relations who are beyond the degree of prohibited relationship, and then only in proportion to the share one will inherit from them upon their death.

\section{3) Maintenance Obligation Under Christian and Parsi Law}

There are no personal laws requiring Christians and Parsis to provide maintenance to their parents. Parents seeking maintenance from their children must file a complaint with the court under Section 125 of the Code of Criminal Procedure, 1973.

\section{4) The Code of Criminal Procedure}

Prior to 1973, there was no provision in the code for the maintenance of parents. The Law Commission, on the other hand, was opposed to such a clause. The Cr.P.C. is not the proper place for such a clause, according to the study. In a summary proceeding of this kind, apportioning the amount of maintenance awarded to parents among the children would be extremely difficult. It is preferable to leave this issue to civil courts to decide. However, the clause was first adopted in 1973 in Section 125 of the Code of Criminal Procedure. It is therefore necessary for the parent to prove that the other party has ample means and has failed or declined to sustain his, i.e., the parent who is unable to support himself. It is important to remember that the Cr.P.C. 1973 is a secular rule that applies to people of all faiths and cultures. Daughters, including married daughters, have an obligation to love and care for their parents.

5) The Senior Citizens Maintenance and Welfare Act of 2007 The Concept of Maintenance - Section 2(b) of the Act 2007 defines "maintenance" as "food, clothes, residence, and medical attendance and care."

The word "welfare" has been specified in section 2 of the bill (k). According to this definition, "welfare" refers to the provision of food, health care, and other necessities for senior citizens. "Parent" refers to a maternal, adoptive, or stepfather or stepmother, depending on the situation, whether or not the father or mother is a senior citizen. Any Indian citizen who has reached the age of sixty years or more is referred to as a "senior citizen." According to Section $2(\mathrm{~g})$ of the Act, a "relative" is described as any legal heir of a childless senior citizen who is not a minor and is in possession of or will inherit his property after his death.

\subsection{Maintenance of Parents and Senior Citizens}

\subsubsection{Who Can Make an Application?}

Under section 4 of the Act, 2007,(i) the parents or senior citizens who is unable to maintain themselves from their own earning or out of property owned by them, shall be entitled to make an application against their one or more of his children who is not a minor or against, in case of senior citizens, his relative. (ii) In case, where senior citizens or parents are unable to file a case, they can authorize any other person or organization to file the case or (iii) the Tribunal is itself may take the case as suo moto ${ }^{6}$. To make the application under this section, the applicant has to prove any one of the two essential conditions. i.e., (i) unable to maintain themselves from their own earning or (ii) unable to maintain themselves out of property owned by them. Whether the parents or senior citizens who is not earning or not having own property is eligible to claim maintenance under this Act?

The application filed under this section must be decided within sixty days of the date of service of notice of the application to that individual. In extraordinary circumstances, the Tribunal can extend this sixty-day period up to one more thirty-day period for reasons to be stated in writing. ${ }^{7}$

\footnotetext{
${ }^{4}$ Section 2(d) of the Act, 2007.

${ }^{5}$ Section 2(h) ibid.

${ }^{6}$ Section 5 of the Act, 2007.

${ }^{7}$ Section 4(4) of the Act, 2007
} 
Non-compliance with the order If any person ordered to pay maintenance or expenses of the proceeding fails to comply with the order without reasonable reason, the Tribunal may issue a warrant for levying the amount ordered and may sentence the defaulter for the entire or any part of each month's allowance for maintenance or expenses of the proceeding that remains unpaid. ${ }^{8}$ The important thing to remember is that in order for the warrant to be issued under this clause, an application to the Tribunal to levy the amount must be submitted within three months of the date on which the amount becomes due. ${ }^{9}$

\subsubsection{Is This Act Applicable to Persons/Relatives Who Live Outside of India's Territory?}

Subsection (2) of Section 1 of Chapter I declares that this Act also applies to Indian citizens living outside of India. Section 6 (5) also addresses the summons service process. "Where the children or relative resides outside India, the Tribunal shall serve the summons by such authority as the Central Government specifies in this regard," it says. The Tribunal is created. The Tribunal is presided over by an officer not lower than the rank of Sub Divisional Officer of a State, as per Section 7(2) of the Act, 2007. The Tribunal has the power to order maintenance in the sum of Rs.10,000/every month. ${ }^{10}$ Any senior citizen or parent who is dissatisfied with a Tribunal's decision may file an appeal with the Appellate Authority within sixty days of the date of the decision. ${ }^{11}$ An officer with the rank of District Magistrate or higher shall preside over the Appellate Tribunal. ${ }^{12}$

\subsubsection{Security of Senior Citizens' Lives and Property "Transfer of Property to be Void in Certain Circumstances}

1) Where any senior citizen has transferred his property by way of gift or otherwise after the commencement of this Act, subject to the condition that the transferee shall provide the basic amenities and basic physical needs of the transferee, the transferee shall provide the basic amenities and basic physical needs of the transferee, the transferee shall provide the basic amenities and basic physical needs of the transferee, the transferee shall provide the basic amenities and basic physical needs of the In certain situations, there is a maintenance option. ${ }^{13}$

\subsubsection{Parents or Senior Citizens Have the Option of Claiming Maintenance}

Under Section 12 of the Act, 2007, even though they are ineligible under Section 125 of the Code of Criminal Procedure, 1973. However, in both Acts, this is not the case. Section 125 of the Cr.P.C. and Section 9 of the Act of 2007 are compared. The maximum amount of maintenance that can be awarded under Section 125 of the Cr.P.C is $\$ 10,000^{14}$, while under the Act of 2007 , the maximum amount of maintenance that can be awarded is $\$ 10,000$. They cannot say more than 10,000/- rs because of a particular bar in section 12 .

\subsubsection{The Maintenance and Welfare of Parents and Senior Citizens (Amendment) Bill, 2019}

The Maintenance and Welfare of Parents and Senior Citizens (Amendment) Bill, 2019, is a bill that amends the Maintenance and Welfare of Parents and Senior Citizens Act.Mr. Thawarchand Gehlot, Minister of Social Justice and Empowerment, introduced the Maintenance and Welfare of Parents and Senior Citizens (Amendment) Bill, 2019 in the Lok Sabha on December 11, 2019. The bill modifies the 2007 Act on the Maintenance and Welfare of Parents and Senior Citizens. The bill aims to accomplish the following objectives:

A. broaden the Act's reach by changing the meanings of "children," "parents," "maintenance," "welfare," and "senior citizens" to allow parents and senior citizens to live dignified lives; the word "children" applies to children and grandchildren, not minors. Step-children, foster children, children-in-laws, and the legal guardian of minor children are now included in the classification. Furthermore, the Act describes a relative as a childless senior citizen's legal heir, except minors, who own or may inherit his property after his death. This is changed in the bill to include minors who are represented by legal guardians. Parents are described in the Act as biological, adoptive, and stepparents. The bill broadens the concept of parents to include grandparents and in-laws.

Maintenance is described in the Act as the provision of food, clothing, housing, medical care, and treatment. Meat, housing, and other necessities for senior citizens are included in the definition of welfare. The bill broadens the meanings of I maintenance to include providing healthcare, protection, and security for parents and senior citizens to

\footnotetext{
8 Section 5(8) of the Act, 2007.

9 Proviso to section 5 (8) of the Act, 2007

10 Section 9(2) of the Act, 2007.

${ }^{11}$ Section 16(1) of the Act, 2007

12 Section 15(2) of the Act

${ }^{13}$ Section 23(1) of the Act, 2007

${ }^{14}$ Section 9(2) of the Act, 2007
} 
live a dignified life, and (ii) welfare to include providing housing, clothing, safety, and other services required for a senior citizen's or parent's physical and mental well-being.

B. broaden the options for submitting a maintenance application by parents or senior citizens;

C. ensures that maintenance applications are dealt with quickly. Subsection 5 of section 5(4) The Tribunal must decide on any application filed under sub-section (1) within ninety days of receiving it: Provided, however, that in the case of senior citizens aged eighty or older, the application must be decided within sixty days: Furthermore, the Tribunal can only extend such duration once for a maximum of thirty days in extraordinary circumstances and for reasons to be reported in writing.

D. Maintenance orders (remove the upper limit of ten thousand rupees as a monthly maintenance sum that the Tribunal can award): State governments are required to establish maintenance tribunals to decide on the amount of maintenance to be paid to senior citizens and parents under the Act. These Tribunals have the power to order children and relatives to pay parents and senior citizens a monthly maintenance fee of up to Rs 10,000. The bill eliminates the maintenance fee's upper limit. When determining the maintenance number, the Tribunals can weigh the following factors: I the parent's or senior citizen's standard of living and earnings, and (ii) the children's earnings. Children and relatives are required by the Act to deposit the maintenance sum with the appropriate parent or senior citizen within 30 days of obtaining the order. The number of days is reduced to 15 in the bill.

E. gives children and relatives who are aggrieved by the Maintenance Tribunal's order the right to appeal if they continue to pay the maintenance sum as ordered by the Maintenance Tribunal;

F. establish registration and minimum requirements for Senior Citizens' Care Homes, Multi-Service Day Care Centers for Senior Citizens, and Institutions offering Homecare Services for Senior Citizens;

G. creates a Special Police Unit for Senior Citizens in each district and select Senior Citizens Nodal Officers in each Police Station;

H. Maintain a Senior Citizen Helpline;

I. Offenses and penalties (impose harsh penalties on those who neglect or abandon parents or senior citizens): Abandonment of a senior citizen or parent is punishable by up to three months in jail or a fine of up to Rs 5,000, or both, under the Act. The bill increases the punishment to three to six months in jail, a fine of up to Rs 10,000 , or both. If the children or relatives do not comply with the maintenance order, the Tribunal may issue a warrant to levy the due sum. Failure to pay the fine could result in a one-month jail sentence, or until the fine is paid, whichever comes first.

\subsection{The Lacunas in the Existing Legislation}

- This bill contains clauses that increase the likelihood of misuse over beneficial use.

- What if one or more of the Senior Citizen's heirs or children live outside of India or in a location other than the Senior Citizen's home?

- Will the senior citizen be able to live with the heir/children as a result of this?

- May a Magistrate's order be implanted in a foreign jurisdiction to compel him to fulfil his obligations?

- What if the senior citizen is the source of strife? Is it still a good excuse to keep him or her around?

- What happens if a couple only has daughters and no son?

- Would the legislation make it mandatory for the senior citizen's son-in-law to look after him?

- How many senior citizens would one be responsible for looking after?

\subsection{Lacunas in the Proposed Amendment Bill}

- A separate tribunal should be constituted for the implementation of the provisions.

- punishment should be made more stringent by adding a proviso that a person who is employed in government bodies against whom complaints are received they will be suspended with immediate effect, until the pendency of the complaint, and if the disobedient children are found guilty, then the same will be considered as a ground of moral turpitude from dismissal of service. So that they will be stopped from taking advantage of adjournment on the ground that they are not getting the sanctioned leave to attend the hearing as well as it will be beneficial in the sense that the practice of delaying will be curbed.

- How many senior citizens would one be responsible for looking after?

- What is the maximum amount to which a senior citizen is entitled for? 
- Whether the ancestral property acquired by the sons and daughters during the life time of senior citizens through transfer deed be declared void? Or will he be on mercy of the disobedient son/daughter to pay maintenance money and to get rid of him.

- The problem still remains when the senior filed a complaint under this act the disobedient son/ daughter Or their spouses misused the provisions of domestic violence Act, 2005. The proposed bill is still silent on the same. Rather the need of the time is to incorporate such a provision that if the senior citizen filed a complaint under the provisions of the act no other complaint against senior citizen will be maintainable until the final disposal of the same.

\section{Suggestions and Conclusion}

The Maintenance and Welfare of Parents and Senior Citizens Act, 2007, is India's first legislation expressly tailored to the needs of elders. It envisions not only family care of the elderly, but also government responsibility for providing adequate physical facilities and social systems to ensure their welfare. This is a groundbreaking piece of legislation that provides legal backing to the younger generation's moral duty to care for and support their parents and elders.

- Under Section 22(2) of the Act the State Government is empowered to draft an action plan for ensuring the safety of life and property of the senior citizens in their respective States. It is suggested that the Act be amended to empower the Tribunals to order eviction in cases where the ownership of the property is indisputably with the senior citizens.

- To provide justice efficiently and rapidly, the Tribunal created under the Act should be presided over only by a legal practitioner, preferably a retired judge, as they are better prepared for the job.

- Hindi Cinema can play active role by showing this evil on cinemas like in Movie: Baghban Directed by : Ravi Chopra, Produced by : B.R. Chopra, Starcast : Salman Khan, Amitabh Bachchan, Hema Malini. This movie narrates a tale of a of a family where the parents (Amitabh and Hema) sacrifice everything to nurture their four children, only to be left uncared for when they grow old.

- To give effective implementation, awareness should be created among the ageis and Parents.

\section{References}

Article 41, The Constitution of India.

M. Venugopal V. (2014). The District Magistrate Cum on 14 August, 2014.

Retrieved from http://www.legalserviceindia.com/article/1170-Rights-Of-Senior-Citizen.html

Retrieved from https://en.wikipedia.org/wiki/Baghban_(2003_film)

Retrieved from https://prsindia.org/billtrack/maintenance-and-welfare-parents-and-senior-citizens-amendment-bill-2019

Retrieved from https://shodhganga.inflibnet.ac.in/bitstream/10603/181563/8/chapter\%205.pdf

Sec. 125, Code of Criminal Procedure, 1973.

Sec. 20(3), Hindu Adoption and Maintenance Act, 1956.

Sec. 5(4) of The Maintenance and Welfare of Parents and Senior Citizens (Amendment) Bill, 2019.

\section{Copyrights}

Copyright for this article is retained by the author(s), with first publication rights granted to the journal.

This is an open-access article distributed under the terms and conditions of the Creative Commons Attribution license which permits unrestricted use, distribution, and reproduction in any medium, provided the original work is properly cited. 